\title{
THE GERMAN VOICE IN THE "BABELIAN TALE OF MUSEOLOGY AND MUSEOGRAPHY": CREATION AND USE OF TERMS FOR MUSEUM SCIENCE IN GERMANY

\section{MARKUS WALZ}

\section{ABSTRACT/ABSTRACT:}

This terminological study regards the shifting German meaning of four terms from their first appearance up to present time. After its emergence as a more ornamental word $(1727,1744)$, during the whole 19th century, museography was strictly used as the name of an analytical method in classical archaeology and art history - with museology as an accepted synonym. Museology and "Museumskunde" as synonymous denominations of the (postulated) museum science emerged in 1845, "Museumswissenschaft" followed in 1905. The meanings are somewhat fluid by reflecting changeable opinions of the phenomenon as a wished but never realizable science, as the knowledge of experienced museum professionals, as a complementary science of the museum-related subject sciences. Western Germany continued these unclear meanings; Eastern Germany approached to the acceptance of museology as a separate academic discipline and created an ambiguity of "museologist" in 1957 (museum professional or museum assistant). Unified Germany extended this ambiguity to "museology" (museum/museality science or application of sciences in museum practice). Therefore, some authors tried to establish different meanings of those three terms without reaching a common sense only "Museumskunde" lost its use as denomination of the academic discipline.

\section{Německý hlas v „babylonském př́iběhu muzeologie a muzeografie“": vytváření a používání názvů pro muzejní vědu v Německu}

Tato terminologická studie se zabývá problematikou významového posunu čtyř termínů v německém jazyce, od jejich prvního výskytu až do současnosti. Po svých počátcích spíše ve funkci slovní ozdoby $(1727,1744)$ byl pojem muzeografie používán během celého 19. století striktně pro označení analytické metody v klasické archeologii a dějinách umění - termín muzeologie byl považován za jeho synonymum. Pojmy muzeologie a nauka o muzeích (Museumskunde) jako synonymická označení pro (postulovanou) muzejní vědu vznikly v roce 1845 , samotný termín muzejní věda (Museumswissenschaft) byl pak zformulován $\mathrm{v}$ roce 1905. Jejich význam je poněkud variabilní a závisí na změnách náhledu na muzejní fenomén, který byl chápán bud’to jako vytoužený, leč nerealizovatelný vědní obor, nebo jako suma poznatků zkušených muzejníků, či jako doplňková disciplína jednotlivých vědních oborů souvisejících s činností muzeí. Západní Německo v tomto nejednoznačném výkladu uvedených pojmů pokračovalo i nadále, zatímco ve východním Německu se muzeologie etablovala jako samostatný vědní obor a dala tím v roce 1957 vzniknout nejasnostem $v$ definici pojmu muzeolog (profesionální muzejník nebo spolupracovník muzea). Po znovusjednocení Německa se tato nejednoznačnost rozšíríila také na pojem muzeologie jako takové (věda o muzeích/muzealitě nebo uplatnění vědy $\mathrm{v}$ muzejní praxi). Někteří autoři se proto snažili zmíněné tři termíny významově odlišit, ale shody dosáhli jedině $\mathrm{v}$ tom, že pojem nauka o muzeích (Museumskunde) se přestal používat pro pojmenování vědního oboru.

\section{KEYWORDS/KLÍČOVÁ SLOVA:}

museography - museology museologist - terminology muzeografie - muzeologie muzeolog - terminologie

It is well known that Germany was the origin of the first museological terms, museography and museology. Most of the relevant German texts (published in the 18th and 19th century) were rediscovered by Peter van Mensch 
and François Mairesse. ${ }^{1}$ Germany was as well first in the description of collections and in theory-building for collections during the "pre-museum era". ${ }^{2}$ Early German texts are regarded as a faint suggestion of interests which later will be called museology. ${ }^{3}$ On the other hand, a recent German article mentions an actually growing plurality of German terms beneath the "traditional terms museology and 'Museumskunde' now museum studies, museum science, museum research, museum analysis, museum history, theories of the museum ...". ${ }^{4}$

All this doesn' t mean spreading a German way of thinking all over the world. Aquilina used the metaphor of Babel for "the fact that various languages use the word [museology] differently" and for the "semantic evolution" of terms, including that the term museology "emancipated" itself of the older term museography. ${ }^{5}$ German origin means a language barrier for many foreign scientists. This barrier already disturbs

1 MAIRESSE, François and André DESVALLÉES Muséologie. Regard \& analyse. In DESVALLÉES, André and François MAIRESSE (eds.).

Dictionnaire encyclopédique de muséologie.

Paris: Armand Colin, 2011, pp. 346-348;

MENSCH, Peter van. Towards a methodology of museology. Zagreb: University of Zagreb, 1992 chapter 2 (no pagina). PhD thesis [accessed 2006-12-23; actually not available]. Has been available from www: <http://www.muuseum. ee/et/erialane_areng/museologiaalane_ki/ ingliskeelne_kirjand/p_van_mensch_towar $>$. 2 WAIDACHER, Friedrich. Handbuch der Allgemeinen Museologie. 2nd edition. Wien: Böhlau, 1996, pp. 125-134; MAROEVIĆ, Ivo. Introduction to museology: the European approach Munich: Müller-Straten, 1998, pp. 74-75.

3 MAIRESSE, François and André DESVALLÉES Brève histoire de la muséologie, des Inscriptions au Musée vivant. In MARIAUX, Pierre Alain (ed.). L'objet de la muséologie. Neuchâtel: Institut d'Histoire de l'art et de Muséologie, 2005, p. 10.

4 MEYER, Andrea and Bénédicte SAVOY. Transnationale Museumswissenschaften. In KAMEL, Susan and Christine GERBICH (eds.). Experimentierfeld Museum. Internationale Perspektiven auf Museum, Islam und Inklusion. Bielefeld: Transcript, 2014, p. 117. [Here and in the following analysis, all quotations are English translations of original German texts, translated by Markus Walz.]

5 AQUILINA, Janick Daniel. The Babelian tale of museology and museography: a history in words. Museology, International scientific electronic journal, 2011, Issue 6, pp. 1-20; here: p. 2. [this electronic journal is actually not available]. quotations of German names. The author of an often referred book decided to write his name on the book title in a Latinized way. He invented "Neickelius" (on the book title in dative case, "Neickelio"); the preface of this book explains in German how to solve this cryptogram of "Jenckel". The German normed database for names spells it "Jencquel" following the tradition of the author's family (merchants wishing to simplify the pronunciation for their Spanish customers $^{6}$ ).

\section{Aim and method of this article}

Aquilina's hypothesis of a semantic evolution didn' $t$ include the historical meaning of those two terms which emerged in Germany their historical use was degraded to one of those unknown and in the meantime lost "Babelian" meanings or subsumed as one item of Aquilina's general impression that museology and museography were "understood either as the description of museums and their collections or as the techniques associated with the management and presentation of collections". ${ }^{7}$

This situation invites to re-lecture early German texts and to search some more instances of certain use of terms. The aim is to clarify historical German meanings of selected terms, to look for continuities of these meanings up to recent times, and to re-interpret the relation of reference texts to (museological) terminology.

This is a study in historical meanings of terms, not in the development of academic disciplines or theories. Therefore, the method for getting more

\footnotetext{
6 SCHRÖDER, Hans. Lexikon der hamburgischen Schriftsteller bis zur Gegenwart. Vol. 3. Günther Kleye. Hamburg: Perthes-Besser \& Mauke, 1857, pp. 488-489.

7 AQUILINA, Janick Daniel. The Babelian tale of museology and museography: a history in words. Museology, International scientific electronic journal, 2011, Issue 6, p. 11
}

evidences than the already known texts is the (electronic) search of key words used either in the title or in the main text of publications; the dominant means are the meta-catalogue of (nearly) all German academic libraries "Karlsruher Virtueller Katalog" and the full-text search of Google Scholar. Google Scholar depends on Google's digitization campaigns, rests fragmentary, and shows some false hits (e. g. "Muscologie" read as "Museologie"), but an alternative instrument is missing. Additionally, digital copies of publications with relevant title words which are stored outside of the Google Empire are searched through if a full-text search is offered, e. g. the journal Zeitschrift für allgemeine Museologie und verwandte Wissenschaften. ${ }^{8}$ Only some selected analogous documents are checked, e. g. the first series of the journal Museumskunde.

Before starting, it is necessary to explain German denominations of academic disciplines. Aquilina concentrated his study on museology and museography. German language knows compound nouns with "-logie" and "-graphie" as well, but additionally with "-kunde" (study, information): "Erdkunde" means geography; "Tierkunde" means zoology "Museumskunde" should mean museology. A fourth option is given by "-wissenschaft" (science), e. g. "Erziehungswissenschaft" (educational science). Consequently, this research looks for four German terms and their meaning.

\section{Some differentiations are} international - geography and geology indicate separate sciences. Quite often, compound nouns with "-kunde" have a popular touch,

\footnotetext{
8 Zeitschrift für allgemeine Museologie und verwandte Wissenschaften, 1 (1878) or rather Zeitschrift für Museologie und Antiquitätenkunde und verwandte Wissenschaften 2 (1879) - 8 (1885). [online]. [accessed 2018-11-22]. Available from www: <http://digital.slub-dresden.de/ werkansicht/dlf/103228/1/>.
} 
the Old Greek suffixes sound more intellectual: "Erdkunde" is a school subject and a title of textbooks, "Geographie" is lectured at university. Most compositions with "-wissenschaft" belong to the 20th century. Art history saw several discourses on the aims of the discipline with a temporary differentiation between

"Kunstwissenschaft" (art science) and "Kunstgeschichte" (art history). The plural as an umbrella term for a group of disciplines is usually constructed with "-wissenschaften", e. g. "Sozialwissenschaften" for sociology and politology. As well ambiguity can be shown: Western Germany used "ethnography" synonymously for field work, a method of ethnology; Eastern Germany used this word as umbrella term for European ethnology and extra-European ethnology.

Nevertheless, "Museographie", "Museologie", "Museumskunde", and "Museumswissenschaft" can as well function in an identical meaning. The metaphoric use of terms can be neglected, only one was found: Richard Weiss, Swiss professor of "Volkskunde", contrasted "Museumswissenschaft" ("museum science", dealing with historical phenomena as such) and "Gegenwartswissenschaft" ("present time science" with the aim to understand present time). ${ }^{9}$

\section{Museography as a baroque headline}

The first appearing museologyrelated term is museography. The author who firstly published this word in 1727 is often quoted as its inventor: Kaspar Friedrich Jencquel ["Neickelius"], salesman at Hamburg. ${ }^{10}$ Till today, his

9 WEISS, Richard. Volkskunde der Schweiz. Grundriss. Erlenbach-Zürich: Rentsch, 1946, p. IX. 10 JENCQUEL, Kaspar Friedrich. Museographia oder Anleitung zum rechten Begriff und nützlicher Anlegung der Museorum, oder Raritäten-Kammern [...]. Leipzig/Breslau: Hubert, 1727. specific use of the term wasn' $t$ noticed although an identical use by Daniel Eberhard Baring followed in 1744. ${ }^{11}$ Jencquel and Baring wrote books in German language but gave them parallel titles in baroque manner, a Latin and a German one. A parallel title was a fashionable way of individualising a publication; a parallel title in Old Greek or Latin signalised intellectual ambitions. Therefore, both authors selected "museographia" as their first title word. It isn' t helpful to discuss the content of their books for understanding what museographia means - these books don' $t$ necessarily contain any museography but they as those books were called museography.

Clearly, this title word is not meaningless but the authors took museographia - "writing about museums, description of museums" - for slightly different contents. Jencquel's "Museographia, or: instruction for the correct understanding and useful construction of museums or cabinets of rarities" combined the description of existing cabinets of arts with the discussion how to structure collections, how to organise those cabinets, how to visit them effectively. Jencquel ["Neickelius"] knew the intelligent play on words museum museorum which Michael Bernhard Valentini, professor of medicine at Gießen University, chose as parallel title for his comparable book in 1704 (2nd edition in 1714). As an experimental thought, Jencquel's book wouldn' $t$ lose by the fictional title "Museum museorum, or instruction for ...". Baring's booklet "Museographia Brunsvico Luneburgica, or curious message on museums, treasuries,

\footnotetext{
11 BARING, Daniel Eberhard. Museographia Brunsvico Luneburgica. Oder Curiöse Nachricht Von denen Museis, Schatz-Kunst- und RaritätenCammern, so curiose Herren in den Braunschweig-Lüneburgischen Landen gesammlet und grösten Theils noch heutigen Tages in denselben aufbehalten werden. Lemgo: Meyer, 1744.
}

cabinets of arts and rarities, as curious gentlemen collected in the principalities of Braunschweig-Lüneburg ..." reported well-known cabinets of arts and enumerated the most important curiosities like a tourist guide. The Latin title is a quite close but shortened translation of the German one.

Both authors never used the term museography inside. Concerning Jencquel ["Neickelius"], Aquilina declared "the word is only used a handful of times within its pages" without giving any reference. ${ }^{12}$ Both digital open-access copies ${ }^{13}$ don' $t$ offer a full text search in function, but the traditional typography (German text in Gothic print, foreign words in roman types) simplifies searching. I found it only two times, both in comments of Johann Kanold referring to Jencquel's work by the book title. ${ }^{14}$

\section{Museography / museology as a method of archaeology and art history}

Jencquel ["Neickelius"] and Baring had no terminological ambitions. The German history of terms for museology began in the early 19th century. Director of the Royal Saxonian collection of antiques Carl August Böttiger gave a course of lectures on classical archaeology in 1806 which was printed in

\footnotetext{
12 AQUILINA, Janick Daniel. The Babelian tale of museology and museography: a history in words. Museology, International scientific electronic journal, 2011, Issue 6, p. 6.

13 Museographia Oder Anleitung Zum rechten Begriff und nützlicher Anlegung der Museorum Oder Raritäten-Kammern... In Bayerische StaatsBibliothek digital [online]. [accessed 2018-11-22]. Available from www: <https://reader. digitale-sammlungen.de/de/fs1/object/display/ bsb10522844_00003.html >; Museographia Oder Anleitung Zum rechten Begriff und nützlicher Anlegung der Mvseorvm, Oder RaritätenKammern... In Digitale Sammlungen [online]. Universitäts- und Landesbibliothek Münster [accessed 2018-11-22]. Available from www: $<$ https://sammlungen.ulb.uni-muenster.de/urn/ urn:nbn:de:hbz:6:1-15073>.

14 JENCQUEL, Kaspar Friedrich. Museographia oder Anleitung zum rechten Begriff und nützlicher Anlegung der Museorum, oder Raritäten-Kammern [...]. Leipzig/Breslau: Hubert, 1727, p. 143.
} 
the same year. The second of its four chapters presented the relevant museum collections and described their classical museum objects. Böttiger called this " $a$ survey of the existing art galleries or [...] a summary of the so-called museography". ${ }^{15}$ A second course of lectures exclusively dealt with the "periegesis" of classical art as the basis for its "exegesis"; this "appearance" of classical arts was realized by museography, ${ }^{16}$ "a promenading visit of the best museums and collections of antiques". ${ }^{17}$ This metaphor sounds like a tourist guide book but the meaning is different: Böttiger's museography is the "revision of those museum collections, well organised by a certain classification and formal typology for explaining the main content of archaeology". ${ }^{18}$

The worldwide first manual of classical archaeology was written by professor for classical philology at Göttingen University Karl Otfried Müller. ${ }^{19}$ The first edition appeared in 1830 , followed by revised editions (1835, 1848, 1878), by English and French translations. He presented his "systematic" chapter in three different ways of geographical order: first, the topography of classical art, second, the theory of the archaeological sites, and third, museography "as a guide for all learners". Obviously, he followed Böttiger but developed

15 BÖTTIGER, Carl August. Andeutungen zu vier und zwanzig Vorträgen über die Archäologie im Winter 1806. Dresden: Arnold, 1806. Vol. 1 , p. XVII.

16 Here and following, the English terms museography and museology are used for easier reading instead of the German "Museographie" and "Museologie" in the source material.

17 BÖTTIGER, Carl August. Ueber Museen und Antikensammlungen. Eine archäologische Vorlesung, gehalten den 2. Januar 1807. Leipzig: Dyk, 1808, p. 5.

18 BÖTTIGER, Carl August. Andeutungen zu vier und zwanzig Vorträgen über die Archäologie im Winter 1806. Dresden: Arnold, 1806. Vol. 1, p. XVII.

19 FITTSCHEN, Klaus. Karl Otfried Müller und die Archäologie. In CALDER, William M. III and Renate SCHLESIER (eds.). Zwischen Rationalismus und Romantik. Karl Otfried Müller und die antike Kultur. Hildesheim: Weidemann, 1998, p. 193. the complete topography of the arts. Architecture only has a single topography (if the buildings or their ruins still exist), but sculpture and painting know three localisations: their original and still factual locality, the excavation site, and the place where the object is actually kept. Müller agreed Böttiger: the original topography and the excavation site primarily serve the researcher as important means of critic and hermeneutic, whereas museography helps the learner like a guide. ${ }^{20}$

\section{Müller's (and Böttiger's)}

museography was a complementary subject to art history

and archaeology. A more

methodological view was given by Bernhardy in 1832. Museography and topography of art might be means for developing knowledge of art history, but he stressed the work on the content with both the historical (chronological) and the geographical point of view for getting the "organism" of classical archaeology (or art history) as precondition of any interpretation of "spirit and content" of art. ${ }^{21}$

Müller's literary references for museography began with Böttiger and were headed "concerning museology". ${ }^{22}$ This term appeared here once in the whole book with 618 pages, no explanation of the term is given: obviously, Müller used museology as a synonym of museography.

The first book with the title word museology was published in 1839: "Structure of Dutch art history and museology". As I supposed that Müller did, it understood museology in the way of Böttiger's museography: Georg Rathgeber, librarian and custodian of the

\footnotetext{
20 MÜLLER, Karl Otfried. Handbuch der Archäologie der Kunst. Breslau: Max, 1830, p. 282. 21 BERNHARDY, G. Grundlinien zur Encyklopädie der Philologie. Halle: Anton, 1832, p. 343. 22 MÜLLER, Karl Otfried. Handbuch der Archäologie der Kunst. Breslau: Max, 1830, p. 284.
}

numismatic collection of the Duke of Gotha, catalogued the coins and medals of the Duke's Museum at Gotha. As an introduction, he described the insufficient situation of art history as collected artist biographies or the description of art collections without any system. "That scientific situation moved me to concentrate on systematizing Dutch museology and art history and to subordinate any other topic to this principal aim." A reader in the 21 st century feels a double meaning of museology because Rathgeber tried to design an order of art works "which should serve to the preservation of art works in collections and to their description in catalogues" but this depends on Rathgeber's focussed view: in his eyes, all contemporary galleries were in disorder and he didn' t know any other kind of systematizing than the academic order. "By the foundation of museology, the way to the history of Dutch art shall be prepared in such a kind that [...] no later author is allowed to deviate." ${ }^{23}$

Rathgeber declared to use separate chronologies for architecture, sculpture, and painting (including graphic arts). He stressed the fact that none of the art historians knew all collections and differentiated the description of personally visited collections (like Böttiger's and Müller's museography) and "the interest in the structure of the integral whole": ${ }^{24}$ museology (or museography) as a structured description of museum collections leads to analytically based art history - and this reflected art history may correct the "right" order of collections. It is true that the use of the terms museology and museography was "somewhat

23 RATHGEBER, Georg. Aufbau der niederländischen Kunstgeschichte und Museologie: Niederländische Münzen und Medaillen des Herzoglichen Museums zu Gotha. Weißensee: Grossmann, 1839. Vol. 1, p. II.

24 Ibidem, vol. 1, p. III. 
uncertain", ${ }^{25}$ but this depends on other authors without Böttiger's, Müller's, and Rathgeber's clear methodological perspective.

The first journal with the title word museology appeared between 1878 and 1885 as a private initiative of director of the Royal Saxonian treasury "Green Vault" at Dresden, Johann Georg Theodor Graesse: "Journal for general museology and related sciences", since 1879 headed as "Journal for museology and the studies of antiquities and related sciences". The first issue declared that this journal is concentrated on applied arts and on information about assets in public and private collections as well as assets in commercial situations and auctions. "The content of this journal will be a double one: a report of the endlessly varied, spread, rarely known material of bigger and smaller art collections and simultaneously a journal for all articles concerning the discipline of arts and antiques." 26

The German meaning of museography (museology) as a topography of museum collections survived till the early 20th century without concurrent meanings. A classification for academic libraries, published in 1863, enumerated museography as a subdivision of fine arts ("description and history of art museums (galleries), cabinets of art and antiques etc."). Interestingly, the analogous subdivision of natural history was called "collections of naturalia", not museography; history science and “cultural history" didn' t get such

\footnotetext{
25 MAIRESSE, François and André DESVALLÉES. Brève histoire de la muséologie, des Inscriptions au Musée vivant. In MARIAUX, Pierre Alain (ed.) L'objet de la muséologie. Neuchâtel: Institut d'Histoire de l'art et de Muséologie, 2005, p. 10.

26 GRAESSE, Johann Georg Theodor and T. Moritz HOFMANN. Was wir wollen. Zeitschrift für allgemeine Museologie und verwandte Wissenschaften, 1878 , no. 1 , p. 2.
}

a kind of subdivision. ${ }^{27}$ In 1874 , an archaeologist criticised that relevant reproductions of antiques were spread over illustrated books of art history and museology. ${ }^{28}$ The only somewhat exotic understanding of museography appeared in 1884: Franz Jacobi reconstructed the localisation of antique art works inside the city of Rome in the era of Emperor Augustus (buildings, sculptures, paintings at their original places and called it museography. ${ }^{29}$ Böttiger and Müller would have preferred "historical topography".

Between 1889 and 1896, Franz Joseph Mone published several volumes of his inventory of art works in the Grand Duchy of Baden, subtitling with museography in the exact meaning of Müller ("Topography of art works and museography in Baden with consideration of military architecture"). ${ }^{30}$ Three times in the early 20th century, one of the yearbook series of the Imperial Archaeological Institute published detailed reports on actual excavations and new exhibits in German museums, headed "museography". After two systematically organised reports, the third one (1912) was structured by municipalities and museums. ${ }^{31}$ The last instance of the German meaning of museography dates from 1926 and shows a misunderstanding: A hobbyist

\footnotetext{
27 SEIZINGER, Johann Georg. Theorie und Praxis der Bibliothekswissenschaft. Grundlinien der Archivswissenschaft. Dresden: Ehlermann, 1863, pp. 128,160 .

28 PIPER, Ferdinand. Das christliche Museum der Universität zu Berlin 1849-1874. Gotha: Perthes, 1874, p. 16.

29 JACOBI, Franz. Grundzüge einer Museographie der Stadt Rom zur Zeit des Kaisers Augustus. Part 1. Speyer: Gilardone, 1884

30 MONE, Franz Joseph. Die bildenden Künste im Großherzogthum Baden ehemals und jetzt. Topographie der Kunstwerke und Museographie in Baden mit Berücksichtigung der Militär-Architektur. Karlsruhe: self publishing of the author, 1889-1896.

31 RITTERLING, E. (ed.). Museographie für die Jahre 1910-1912. Bericht der Römisch-Germanischen Kommission, 1912, vol. 7, pp. 26-252.
}

of local history reported the prehistoric finds out of his village which are stored either in the local museum or the state museum at Wiesbaden; he headed this text "museography of the local museum of Schwanheim". ${ }^{32}$

In 1975, director of Nature Museum Senckenberg in Frankfort on the Main Wilhelm Schäfer felt free to use the term in a new way: museography as "the means of typeface and graphic for leading the exhibits to speak and for deepening the message". ${ }^{33}$ He used "Museographie" and "Museographik" synonymously and argued by comparing graphic design for print media and unique graphics or typeface and graphic for museum exhibitions. There is no evidence that he knew contemporary discourses in foreign languages dealing with museography in a comparable but broader meaning. Schäfer's use of the term hadn' $t$ any succession.

\section{Museology/"Museumskunde"/ "Museumswissenschaft" as the fictive museum science}

In 1845, the first description of museology in its actual meaning was published in Germany. Alexander Held, custodian of the Royal Bavarian cabinet of naturalia at Munich, published his "experiences and instructions about collecting, preparing, classifying, presenting, storing, and demonstrating of the assets belonging to the animal, vegetable, or mineral kingdom". As he firstly mentioned the name of the science concerning collections of naturalia, museology, he wrote it in quotation marks like introducing

$\overline{32 \text { SCHMIDT, W. Museographie des }}$

Heimatmuseums der Gemeinde Schwanheim. Bericht der Freiwillig-tätigen Arbeitsgemeinschaft zur Förderung der Heimatforschung [Frankfurt a. M.], 1926, no. 5, pp. 115-116.

33 SCHÄFER, Wilhelm. Naturwissenschaftliche Grafik - Museographik. In Festschrift für Peter Wilhelm Meister zum 65. Geburtstag. Hamburg: Hauswedell, 1975, p. 288. 
a new term. He proclaimed that museology is a separate entity "connected with several sciences and arts", focussed on collecting and preserving naturalia for scientific education and as "a paradisiacal feast for the eyes". ${ }^{34}$ The similarity to actual discourses and as well to the ICOM definition of museum is astonishing. Held used two obvious synonyms for museology: "Museumskunde" and "Kabinetskunde". For him, a museum was a cabinet of natural history and vice versa.

\section{In 1905, Austrian art historian} and director of the Mährisches Gewerbemuseum at Brno, Julius Leisching, mentioned the fictive "museum science" (being the first calling it "Museumswissenschaft"): "Does such a science exist? It is a pity, not yet". ${ }^{35}$ This contradictory view characterized Germany in the 19th century. Held was sure that it is impossible to think of an "educational institution which would develop the 'Kabinetskunde' to an accepted, independent study programme, winning more solidity and interest by moving into the public". ${ }^{36}$ Graesse compared the perspective of the up-andcoming academics with interest in librarianship or museum work: There were "several publications on the qualification of librarians", but the same question for future museum professionals was "nowhere asked and answered". ${ }^{37}$

34 HELD, Alexander. Demonstrative Naturgeschichte oder Erfahrungen und Belehrungen über das Sammeln, Präpariren, Klassificiren, Aufstellen, Verwahren und Demonstriren der Naturkörper aller drei Reiche. Stuttgart: Hallberg, 1845, pp. VIII-IX.

35 LEISCHING, Julius. Museumskurse. Museumskunde, 1905, vol. 1, p. 93.

36 HELD, Alexander. Demonstrative

Naturgeschichte oder Erfahrungen und Belehrungen über das Sammeln, Präpariren, Klassificiren,

Aufstellen, Verwahren und Demonstriren der Naturkörper aller drei Reiche. Stuttgart: Hallberg, 1845, p. IX.

37 GRAESSE, Johann Georg Theodor. Die Museologie als Fachwissenschaft. Zeitschrift für Museologie und Antiquitätenkunde und verwandte Wissenschaften. 1883 , no. 15, p. 114.

\section{Museology/"Museumskunde" as the application of sciences in museum practice}

The beginning of an article in Graesse's journal Zeitschrift für Museologie und Antiquitätenkunde is often quoted: "If thirty or even twenty years ago anyone had spoken or written about museology as an academic discipline, many people would have responded with a pitying, contemptuous smile. Actually, the situation is different indeed." ${ }^{38}$ The rest of this text doesn' $t$ fit to these pronounced first lines. Graesse discussed the necessary knowledge of museum professionals by quoting contemporary examples (including Böttiger). The term museology appeared two times. The inspector of the armoury of Prince Carl of Prussia, Hiltl, was entitled "a highesteemed name within the literature of museology and the science of arms". ${ }^{39}$ Graesse enumerated a lot of academic subjects - from palaeography to ethnography and called them the "the perfect example of museological studies" (in the meaning of an allround education on university level). ${ }^{40} \mathrm{His}$ main impetus was to propagate the "conditio sine qua non [...] that a museum official of the present time must necessarily have passed the academic career". ${ }^{41}$

Graesse didn' t mention any definitely museological content which could be learnt at university but he stressed necessary experiences with the museum collections which should be gathered by museum work. Graesse's "academic discipline museology" was neither a reality nor a desire but it described the universal knowledge of academics as museum professionals. A similar understanding of "Museumskunde"

\footnotetext{
38 Ibidem, p. 113

39 Ibidem, p. 115.

40 Ibidem, p. 130

41 Ibidem, p. 114
}

can be found in 1891; the author of an illustrated book dealing with skeletons of birds was described as a researcher of great merit in ornithology, anthropology, and "Museumskunde". ${ }^{42}$

Comparable to Graesse's journal, the second German journal on museums and museum work started as a private activity of a museum professional. The art historian Karl Koetschau was director of several high-esteemed German institutions between 1897 and 1936: the Duke's Collections Coburg, the Historical Museum Dresden, the Grand Duke's Museums Weimar, the Art Collection of the City of Düsseldorf, and the Prussian State's Picture Gallery (Emperor Frederick Museum) at Berlin. ${ }^{43}$ Koetschau edited his journal between 1905 and 1924 and called it Museumskunde. The first version of the subtitle, "journal for the administration and technology of public and private collections", signalized the interest in practical museum work and presumably applied sciences.

In the first issue of Museumskunde, an early advocate of "museum courses" presented an opinion very close to Graesse: this Austrian museum director stressed that real life, the museum itself was the best school for museum professionals. In his eyes, the most effective way of learning was neither reading books nor lectures, but intense studies of rich collections, guided by acknowledged experts. ${ }^{44}$ Consequently, an early "Manual of

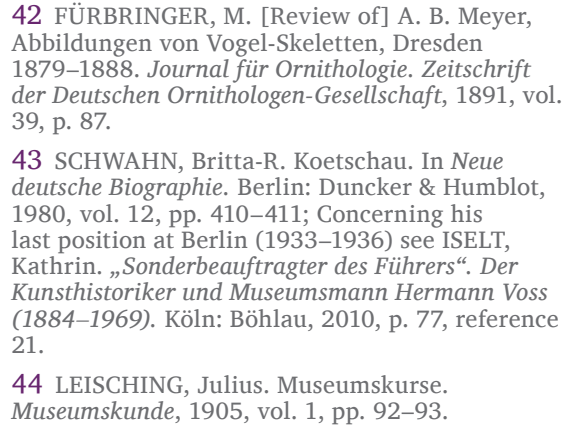


Museum Work" presented itself as the reproduction of lectures and practical exercises organised by the regional museum association. ${ }^{45}$

\section{Museology as a (wrong) name for good museum practice}

The museological literature already quoted a publication which looks quite similar to Held's work. Philipp Leopold Martin, freelance taxidermist at Stuttgart, published a "universal textbook" on natural history collections and zoological gardens in 1871, expanded in 1880; its 2nd volume is headed "Dermoplastic and museology or: modelling of animals and the putting up and the preservation of collections of naturalia". The title of the 5th chapter shows clearly that museology is synonym with "putting up and the preservation of collections of naturalia" - and more: Martin dealt with a lot of good practices, from room functions to air circulation, from exhibition furniture to visualisations of extinct species, from cleaning the showcases to the necessity of visitor toilets. ${ }^{46}$ In contrast to Held, Martin offered nothing but a compilation of practical knowledge in museum work. One might guess that he didn' $t$ think of any educational programme but hoped that his advices were sufficient.

In 1891, Karl Möbius director of the Museum of Natural History at Berlin felt free to use the adjective "museologisch" for a basic decision in exhibition design without thinking of any applied science:

\footnotetext{
45 BERGER, Siegfried. Vorwort. In Praktische Museumsarbeit. Hinweise für Leiter und Helfer von Heimatmuseen. Merseburg: Museumsverband für die Provinz Sachsen und für Anhalt, 1939, pp. 5-7; here: p. 7.

46 MARTIN, Philipp Leopold. Die Praxis der Naturgeschichte. Ein vollständiges Lehrbuch über das Sammeln lebender und todter Naturkörper; deren Beobachtung, Erhaltung und Pflege im freien und gefangenen Zustand; Konservation, Präparation und Aufstellung der Sammlungen etc. Vol. 2. Dermoplastik und Museologie oder das Modelliren der Thiere und das Aufstellen und Erhalten von Naturaliensammlungen. $2^{\text {nd }}$, expanded and revised edition. Weimar: Voigt, 1880, pp. 211-254.
}

he called the signalization of the habitat of exhibited animals by object texts in different colours for the different continents "museological marking". 47

In Koetschau's eyes, “Museumskunde" already reached the position of a "special discipline with an independent importance", because "we [the art historians as museum professionals] already made remarkable progress in forming this special discipline". Nevertheless, this discipline lacked any outline: "Unsystematic professional knowledge is a contradiction within itself although this discipline might be in such a way tied to museum practice, might disappear into museum practice." 48

\section{Museology/"Museumskunde"/ "Museumswissenschaft" as a complementary science}

Leisching mentioned trials of implementing "museum science" at university for example at Innsbruck University (Austria). ${ }^{49}$ Obviously, he misunderstood the facts: Professor for medieval history once taught "Museumskunde" in summer 1904, although he was accustomed to repeat most of his lectures after two or three years. Perhaps, this solitary lecture was one option within the historic complementary sciences like a colleague lectured "practical archive science" in $1907 .{ }^{50}$ Koetschau had different ideas to institutionalise museology. He depicted a kind of summer school for young museum professionals, organised by the German museum

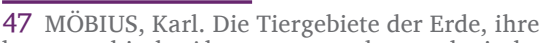
kartographische Abgrenzung und museologische Bezeichnung. Archiv für Naturgeschichte, 1891, vol 57, no. 1, pp. 277-291.

48 KOETSCHAU, Karl. Die Vorbildung der Museumsbeamten. Vortrag, gehalten auf der Würzburger Tagung 1918 [des Deutschen Museumsbundes]. Hamburg: Lütcke \& Wulff, 1918, pp. 2, 5, 11.

49 LEISCHING, Julius. Museumskurse. Museumskunde, 1905, vol. 1, p. 94.

50 I revised the published lecture timetables of Innsbruck University from summer semester 1903 to summer semester 1911 .
}

association: four weeks might be sufficient if it was accepted that the participants were not well skilled in photography at the end of this summer school. ${ }^{51} \mathrm{He}$ also proposed to integrate "the technique of fine arts and "Museumskunde" into the study programme of art history with a special condition: a museum director had to join the academic staff. ${ }^{52}$ Like Graesse, Koetschau regarded museum professionals as the incarnation of museology. Since January $1920,{ }^{53}$ he himself lectured at the Institute for Art History of Bonn University, additionally to his directorship in Düsseldorf. In 1922, the philosophical faculty appointed him honorary professor of "technique of fine arts and 'Museumskunde'".

This first museological professorship in Germany looks like a landmark of historical museology but it must be seen that Koetschau totally gave twenty lectures with technological topics, three with a general content of art history, another three concerning museum work (introduction to collecting art, winter 1923 and summer 1933, "exercises in museum technique", winter 1923). Koetschau was a solitary case by his professorship, not by teaching at university. Another museum professional reported that he lectured at Breslau University since 1930. He held all his seminars at the art museum, combining short lectures with exercises (using real art works) or visits within the museum. ${ }^{54}$

In 1976, Western German ethnologist Horst Nachtigall wrote about "ethnological

\footnotetext{
51 KOETSCHAU, Karl. Die Vorbildung der Museumsbeamten. Vortrag, gehalten auf der Würzburger Tagung 1918 [des Deutschen Museumsbundes]. Hamburg: Lütcke \& Wulff, 1918, pp. 14-15.

52 Ibidem, p. 16.

53 Concerning this aspect and the following data see the published lecture timetables of Bonn University.

54 WIESE, Erich. Museumskunde als Lehrfach. Museumskunde, 1960, vol. 29, pp. 93-95.
} 
museology" and the "museum science within every discipline" ("die Museumswissenschaft jeder Branche"). ${ }^{55}$ Five other ethnologists declared the need for a national institute of museology offering a qualification in museum education for young ethnologists (and presumably as well for graduates of other disciplines) who already got a museum job. ${ }^{56}$

In 1978, the Bavarian museum association (Western Germany) set up a "working group museology" because of an actual discussion to establish museology as a subject at one of the Bavarian universities. This working group declared that museology was only acceptable as a complementary subject of other (museum-related) disciplines. They proposed the foundation of an independent institution "Kolleg für Museumskunde" for developing the study programme; this institution should be composed of experienced museum professionals and university professors. ${ }^{57}$ Nothing happened. In 1980, professor of complementary sciences of archaeology at Frankfort University (Western Germany) Maria Radnóti-Alföldi elaborated an expert's report on a study programme of museology for the federal member state Hessen - without any realisation; she published the text in 1982. She declared strictly that museology couldn' $t$ be an independent subject because "only certain basics and techniques are valid everywhere". Alföldi's museology supplies museum-related disciplines with "the abstract theory of the museum and museum history but predominantly

55 NACHTIGALL, Horst. Politische Probleme der völkerkundlichen Museologie. Zeitschrift für Ethnologie, 1976, vol. 101, no. 2, pp. 299, 300.

56 VOSSEN, Rüdiger et al. Bilanz und Zukunft der Völkerkunde-Museen. Zeitschrift für Ethnologie, 1976, vol. 101, no. 2, p. 199.

57 GRIBL, Albrecht A. Museologische Aus und Fortbildung in Bayern und der BRD. Jahrbuch für Volkskunde und Museologie des Bezirksheimatmuseums Spittal/Drau, 1991, vol. 5, p. 72-73. the practical knowledge and experiences in museum work"; she stressed "techniques" of museum documentation, museum didactics, practice in exhibiting, at least basic knowledge of media technique, restoration, preparation, and conservation. The variety of specialized museologies was touched by the opinion that only the art historian, biologist, etc. would know the scientific background and the interest of the audience to mediate the exhibition content. ${ }^{58}$

\section{Museology/"Museumskunde"/ "Museumswissenschaft" in Western German discourses}

The second issue of the journal Museumskunde after World War II (1960) presented an article of Heinz Ladendorf professor for art history at Cologne University. He criticised "that just Germany which has done so much for the development of general 'Museumskunde' doesn' t yet know a representative of the museum discipline at univer-

sity". He depicted a (non-

-existing) "Museumskunde" widely extended outside art history, with interdisciplinary connections from educational science to psychology, working as well on "theory, psychology, and history of storing things, on the meaning of collecting and preserving". ${ }^{59} \mathrm{~A}$ reaction of universities or museum professionals in Western Germany is missing.

The term museology first re-appeared in imported lectures without effect. In 1971, ICOM [Western] Germany arranged a conference headed "Museology" and invited Georges Henri Rivière for a lecture. Within the

\footnotetext{
58 RADNÓTI-ALFÖLDI, Maria. Museologie. Ein mögliches Ergänzungsfach an der Universität. Bayerische Blätter für Volkskunde, 1982, vol. 9, no. 2 , pp. $80-81$.

59 LADENDORF, Heinz. Museum und Universität. Museumskunde, 1960, vol. 29, pp. 73-87; here: pp. $74-75$
}

publication of the conference, president of ICOM Germany wrote an "Introduction to the Term Museology" without mentioning any definition of this term. ${ }^{60}$ In 1988, ICOM Austria, ICOM [Western] Germany, and ICOM Switzerland organised a joint conference on museology. Zbyněk Stránský was the only person to speak of museology as a separate discipline. ${ }^{61}$

The unsuccessful trials of the 1970ies to establish museology as a complementary science are already mentioned. The first academic reflections in Western Germany about a separate discipline museology were done by the $\mathrm{PhD}$ thesis of a professional in museum education (1980): This (not perfectly structured) book tried "to show the difficulties of museum education on the way to its existence as an independent sub-discipline and to explain the possibility of this independence". Obviously, the author thought of a sub-discipline of museology, always in touch with the relevant subject discipline. ${ }^{62}$

In 1971, the "Deutsche

Forschungsgemeinschaft" - an important state-financed research funding organisation of Western Germany - described a "crisis of the museums" and demanded a "central interdisciplinary research institute for museum methodology" with high interest in visitor studies. In 1980, the "Institut für Museumskunde"

\footnotetext{
60 AUER, Hermann. Zur Einführung in den Begriff Museologie. In Museologie. Bericht über ein internationales Symposium, veranstaltet vom Deutschen Nationalkomitee des Internationalen Museumsrates (ICOM) in Zusammenarbeit mit der Deutschen UNESCO-Kommission, 1971 in Mün München. Pullach: Verlag Dokumentation, 1973, pp. 10-12. 61 STRÁNSKÝ, Zbyněk. Die theoretischen Grundlagen der Museologie als Wissenschaft. In AUER, Hermann (ed.). Museologie. Neue Wege - neue Ziele. Bericht über ein internationales Symposium, veranstaltet von den ICOM Nationalkomitees der Bundesrepublik Deutschland, Österreichs und der Schweiz, 1988 am Bodensee. München: Saur, 1989, pp. 38-47.

62 KUNTZ, Andreas. Technikgeschichte und Museologie. Beitrag zu einer Wissenschaftsgeschichte museumspädagogischer Probleme. Frankfurt am Main: Peter Lang, 1981, pp. 6-7.
} 
opened at Berlin (West), financed by the Federal Republic and all federal member states. ${ }^{63}$ It started with a double focus on museum history and the realization of the museum statistics of the Federal Republic. In 1990, this institute organised a conference on early modern museum history; a lecture concerning the 17 th century collector and theorist of collections, Johann Daniel Major, used the title word "Museumswissenschaft". ${ }^{64}$

\section{Museology ("Museumskunde"/ "Museumswissenschaft") as an academic discipline in Eastern Germany}

The German Democratic Republic (GDR) held its first controversial discussion on museology in the years 1964/65, driven by pragmatism: The official acceptance of a scientific field would make easier to publish texts and start a disciplinary periodical because of guaranteed paper rations and by reduced questions of the state's censorship body. Annadora Miethe, director of the Office for Local and Regional Museums, and her assistant Eberhard Czichon published "Outlines of Theses Concerning the "Museumswissenschaft"' in 1964, starting at the inconsequence to have libraries and library science, archives and archive science, museums but no museum-related science. Five directors of state museums at Dresden recommended a philosophical examination of whether or not a museum science could exist. The Ministry of Culture

63 GROTE, Andreas. Das Institut für Museumskunde bei den Staatlichen Museen Preußischer Kulturbesitz in Berlin. In VIEREGG, Hildegard et al. (eds.). Museumspädagogik in neuer Sicht. Erwachsenenbildung im Museum. Baltmannsweiler: Schneider, 1994, vol. 2, pp. Baltman 381 .

64 STECKNER, Cornelius. Das

Museum Cimbricum von 1688 und die

cartesianische „Perfection des Gemüthes“.

Zur Museumswissenschaft des Kieler

Universitätsprofessors Johann Daniel Major

(1634-1693). In GROTE, Andreas (ed.).

Macrocosmos in microcosmo. Die Welt in der Stube.

Zur Geschichte des Sammelns 1450 bis 1880.

Opladen: Leske \& Budrich, 1994, pp. 603-628. suppressed further discussions by ideological reasons but showed some (low-cost) reaction like appointing an advisory board of the museum system ("Rat für Museumswesen") which undertook the editorship of the museum journal of the GDR Neue Museumskunde. ${ }^{65}$

\section{A similar indecisive situation} concerned the theory of museology developed by Czech docent Zbyněk Stránský. In 1981, the Institute for the Museum System ("Institut für Museumswesen") produced a typewritten translation of Stránský's "Úvod do studia muzeologie" (1979). Klaus Schreiner museum director at Alt Schwerin wrote an Introduction to Museology which was accepted as postdoctoral thesis ("Dissertation B") by Humboldt University Berlin; within that, he criticised Stránský's "questionable closeness to bourgeois values". ${ }^{66}$ He noted that those ideas had "infected" many museologists in the GDR, but mentioned as well that he had not got the approval of the Institute for the Museum System to publish his ideological critique of Stránský. ${ }^{67}$

Nevertheless, there was some motion in museological affairs. In 1978, the Institute for the Museum System translated and published some actual research in applied museology done by the Research Institute for Culture at Moscow. ${ }^{68}$ In 1979, an interdisciplinary working

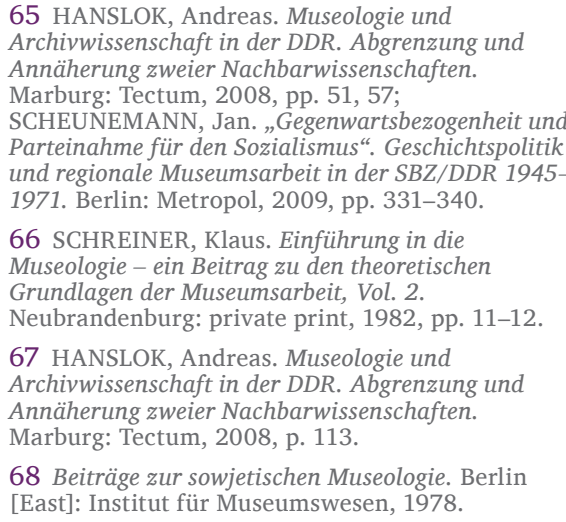

group of the GDR was founded for analysing the state of MarxistLeninist museology and depicting a study programme of museology ${ }^{69}$

In 1980, Ilse Jahn was established as docent of natural history museology at Humboldt University Berlin. She soon issued reports about the first museological dissertation projects ${ }^{70}$ and reflected later the cooperation of the natural history museums in [Eastern] Berlin and Budapest as an evidence of the development of natural history museology ${ }^{71}$. 1988 was the most effective year for museology in the GDR. The Museum of German History, Berlin, presented the results of an intense cooperation with the State Museum of History at Moscow: a handbook of museology (of history) ${ }^{72}$ and a three-day conference Museology and Museum at Berlin. Humboldt University Berlin got a museology "area" within its history section and started a postgraduate study programme of museology (of history) in the same year. ${ }^{73}$ At the Berlin conference in 1988, director of the institute of further education of museologists at Moscow Avram Razgon explained that the socialist countries are absolutely first in museological research; he explicitly mentioned

\footnotetext{
69 AVE, Joachim. Museumspraxis und Museologie. Beiträge und Mitteilungen [Museum für Deutsche Geschichte Berlin], 1988, no. 14, p. 41.

70 JAHN, Ilse. Bemerkungen über museologische Forschung zu Problemen naturhistorischer Museen. Museologische Forschung. Beiträge und Informationen, 1982, vol. 3, pp. 3-6.

71 JAHN, Ilse. Der Freundschaftsvertrag zwischen dem Museum für Naturkunde Berlin und dem Naturhistorischen Museum Budapest und die Entwicklung einer naturhistorischen Museologie. Berichte zur Wissenschaftsgeschichte, 2001, vol. 24, pp. 155-162.

72 HERBST, Wolfgang and K. G. LEVYKIN (eds.). Museologie. Theoretische Grundlagen und Methodik der Arbeit in Geschichtsmuseen. Berlin [East]: Deutscher Verlag der Wissenschaften, 1988.

73 AVE, Joachim. Museumspraxis und Museologie. Beiträge und Mitteilungen [Museum für Deutsche Geschichte Berlin], 1988, no. 14, pp. 41-42.
} 
the "special museology of natural sciences" in the GDR. ${ }^{74}$

Because of these developments, the GDR knew two different models - the museology of nature and that one of history - with partly contradictory opinions of the structure and methodology of this discipline. Close to the Peaceful Revolution of 1989, the GDR saw vivid museological discourses with a clear terminological preference for museology - only Razgon's (translated) lecture offered once "Museumskunde" and "Museumswissenschaft" besides the repeated "Museologie".

\section{Museologist/ \\ "Museumswissenschaftler": a derived but ambiguous term}

Held once presented the neologism "museologist" ("der Museolog") for museum professionals. ${ }^{75}$ Obviously, he differentiated the qualified professionals in the cabinet, including the director, and other staff: "experienced, earnest, and skilful men who are able to meet all demands on the field of "Museumskunde", contrasting to "the aliens in 'Museumskunde"" who have to be supervised by the museum director. ${ }^{76}$

One time, the journal of the Germanic National Museum at Nuremberg wrote "museologists" for pointing to very prominent researchers of the museum. ${ }^{77}$ Otto Lauffer director of the History Museum of Hamburg explained 1907: "The duty of the museologist

\footnotetext{
74 RAZGON, Avram M. Entwicklungen und Perspektiven der modernen Museologie. Beiträge und Mitteilungen [Museum für Deutsche Geschichte Berlin], 1988, no. 15, pp. 23, 25.

75 HELD, Alexander. Demonstrative Naturgeschichte oder Erfahrungen und Belehrungen über das Sammeln, Präpariren, Klassificiren, Aufstellen, Verwahren und Demonstriren der Naturkörper aller drei Reiche. Stuttgart: Hallberg, 1845, p. XVI.

76 Ibidem, pp. 534, 535.

77 STEGMANN, Hans. Zur Geschichte der Herstellung und Verzierung der geschlagenen Messingbecken. Mitteilungen aus dem germanischen Nationalmuseum. 1899, no. 3, p. 19.
}

is to arrange the exhibits within the different groups of objects in a scientific correct way and as well in such an aesthetic way that the prominent educational content of the exhibits is pleasantly presented to the audience." 78

Rarely, the term "Museumswissenschaft" was used as a collective synonym of museologist. So it was written in 1933, that the "Museumswissenschaft" under the art historians visiting a congress in 1908 won the discussion if a national organisation of art historians should be founded or not. ${ }^{79}$ A comparable use of "museum scientists" can be found in 1976: a report of five ethnologists on the situation of ethnological museums in Germany talked about ethnologists working in museums as "Museumswissenschaftler". 80

In the 1990ies, a specific use of the term museologist became visible. The German cultural anthropology ("Volkskunde") saw several controversies between university staff and academics working in museums. During the controversy of 1993/94, professor of "Volkskunde" at Göttingen University Carola Lipp criticized some statements of two highly respected museum directors (both as well docents of "Volkskunde" at Münster University). She delicately shifted her comments between "colleagues" (in a positive or neutral meaning) and "museologists" (in a perhaps

\footnotetext{
78 LAUFFER, Otto. Das historische Museum: Sein Wesen und Wirken und sein Unterschied von den Kunst- und Kunstgewerbe-Museen. Museumskunde, 1907, vol. 3, p. 235

79 WULFF, Oskar. August Schmarsow zum 80 Geburtstag. Zeitschrift für Kunstgeschichte, 1933 vol. 2, no. 3, p. 209.

80 VOSSEN, Rüdiger et al. Bilanz und Zukunft der Völkerkunde-Museen. Zeitschrift für Ethnologie, 1976, vol. 101, no. 2, pp. 198, 199.
}

neutral or obviously critical meaning). ${ }^{81}$

The German Democratic Republic (East) created a separate meaning of "museologist". Since 1954, a national educational institution existed for museum staff below the university level, needed as well as assistants in bigger museums and as solitary professionals in small museums. Therefore, a job outline for museum professionals with a definite job title was needed. A preceding educational structure (Weimar, 1951) finished with an exam as "Museumskundler". The Ministry for Culture discussed the neologism "Musear" - analogously to "Archivar" (archivist) and "Bibliothekar" (librarian) -, started with "Museum Assistant" but in 1957, chose "Museologe" (museologist). ${ }^{82}$ The first title of the museum-related learning units was "Museumskunde". In 1966, it changed to "Museologie" but the Ministries of Higher Education and of Culture still used "Museumskunde" in $1984 .{ }^{83}$

This job title "museologist" didn' t suppress older meanings of the term: In 1971, general director of the national memorials at Weimar talked about "the museologist, he might be an art historian, historian of literature, historian or natural scientist". ${ }^{84}$ At the conference Museology and Museum in 1988, und Sachkulturforschung. Eine Antwort auf die kritischen Kommentare der Museologen Helmut Ottenjann und Uwe Meiners. Volkskunde in Niedersachsen, 1994, vol. 11, no. 2, pp. 85-93.

82 SCHEUNEMANN, Jan. ,... dass für Dinge die einen so geringen gesellschaftspolitischen Nutzen haben so ein Aufwand gemacht wird." Fachschulausbildung von Museumsassistenten und Museologen in der DDR 1954-1964. In SCHIMPFF, Museologen in der DDR 1954-1964. In SCHIMP
Volker and Wieland FÜHR (eds.). Historia in museo. Festschrift für Frank-Dietrich Jacob zum 60. Geburtstag. Langenweißbach: Beier \& Beran, 2004 pp. 396-401, 411

83 BREUER, Werner. Die Entwicklung der Fachschule für Museologen 1954-1984. In Studien zur Geschichte des Museumswesens und der Museologie. Vol. 1. Berlin: Institut für Museumswesen, 1983, p. 27.

84 HOLTZHAUER, Helmut. Museumspädagogik und Museumswissenschaft. Neue Museumskunde, 1971, vol. 14 , no. 2 , p. 88. 
a historian of the Museum of German History talked about "our work as museologists at a history museum" and confessed "We are historians, museum-oriented [...] but just historians." 85

\section{Unification of Germany, differentiation of terminology}

The international discourse concerning the developing discipline museology got little interest in Germany. Even in the GDR, the lack of international comparisons was criticized ${ }^{86}$ although the GDR was integrated in the museological discourse of the Eastern bloc. A broader awareness grew after the German unification initiated by Friedrich Waidacher, musicologist and director of Austria's second biggest museum, Museum Joanneum at Graz. This Austrian elaborated a theoretical position close to Stránský and in 1993, he presented his Handbook of General Museology; a revised 2 nd and a 3rd edition counted 792 pages. ${ }^{87} \mathrm{He}$ used the term museology consequently; other terms only appeared within quotations. In 2005, Katharina Flügel, professor of museology at Leipzig University of Applied Sciences, presented an Introduction to Museology following Stránský's and Waidacher's ideas. ${ }^{88}$

As the only GDR institution, the College of Museologists survived by transformation into a study programme named Museology at the new Leipzig University of Applied Sciences. The job

85 RADEMACHER, Hellmut. Historische Bildkunde im Geschichtsmuseum. Beiträge und Mitteilungen [Museum für Deutsche Geschichte Berlin], 1988, no. 16, p. 24.

86 RÖSSLING, Udo. Museologie und die Zeitschrift „Neue Museumskunde“. Beiträge und Mitteilungen [Museum für Deutsche Geschichte Berlin], 1988, no. 15, p. 79.

87 WAIDACHER, Friedrich. Handbuch der Allgemeinen Museologie. 2nd edition. Wien: Böhlau, 1996, pp. 125-134.

88 FLÜGEL, Katharina. Einführung in die Museologie Darmstadt: Wissenschaftliche Buchgesellschaft, 2005. title "Museologe" changed to an academic diploma as museologist. The journal of the German Museum Association published a very positive comment but remarked the "not appropriate" denomination because museology would go beyond the frame of collection management, the focus of the study programme. ${ }^{89}$ Waidacher proposed the academic degree "Diplom-Museumsassistent" unsuspecting that his "creation" repeated the first version of the GDR job title.

Obviously, the growing acceptance of these certificates stimulated a differentiation of terms pre-formulated by two study programmes for museologists and confrontations of their leading professors on the need of museology for practical museum work - Katharina Flügel (Museology at Leipzig) and Angelika Ruge ("Museumskunde" since 1993 at Berlin University of Applied Sciences). Flügel strictly declared that "Museumskunde" were neither a science nor a synonym of museology; as a retrospective transfer, she guessed that Koetschau used "Museumskunde" for separating his interest in practical museum work from (more theoretical) museology. ${ }^{91}$ Waidacher proposed "Museumskunde" as a subset of museology; ${ }^{92}$ presumably a transfer of the French use of "museography". In 2006, the national "Institut für Museumskunde" changed its

89 KLAUSEWITZ, Wolfgang. Kommentar der Redaktion. Museumskunde, 1992, vol. 57, no. 1, pp. 64-65.

90 WAIDACHER, Friedrich. Grundgedanken zu einer museologieorientierten Praxis. Museologie online [online]. 2001, vol. 3, p. 95 [accessed 2018-08-30]. Available from www: <http://www. historisches-centrum.de/m-online/>

91 FLÜGEL, Katharina. Einführung in die Museologie. Darmstadt: Wissenschaftliche Buchgesellschaft, 2005, pp. 8, 16.

92 WAIDACHER, Friedrich. Grundgedanken zu einer museologieorientierten Praxis. Museologie online [online]. 2001 , vol. 3 , p. 85 [accessed 2018 08-30]. Available from www: <http://www. historisches-centrum.de/m-online/ $>$. name to "Museumsforschung" (museum research) for avoiding any misunderstanding. Newly founded study programmes at Würzburg University reflect this changed terminology: the bachelor programme "museology and material culture" (since 2010) prefers applied sciences in analogy to the diploma as museologist. The master programme accentuates museum-related research and got the name "Museumswissenschaft" (since 2013).

Rarely, the plural "Museumswissenschaften" appeared. Gottfried Korff once used it for disciplines influencing museum practice or museum theory. ${ }^{93}$ President of the International Committee for Museology Hildegard Vieregg invented her personal version of "Museumswissenschaften": these disciplines "mainly deal with museum history, museology, museum education, and museum didactics". Vieregg's museum history can' $t$ be a separate science because she announced that it overlaps with museology, museography, and educational aspects. ${ }^{94}$ She published an "actual" definition of museology as "the museum in its historical context, the museum as a societal institution, and research concerning all functions and duties of museums as a whole"; in her eyes, important aspects of museology are philosophy, futurology, epistemology, and methodology of museology as well as museum ethics. ${ }^{95}$

Except of the single use by Vieregg, the German term

\footnotetext{
93 KORFF, Gottfried. Igel oder Kuscheltier? Anmerkungen zur Situation des Museums im Medienwandel der Informationsgesellschaft. In SIMON, Michael et al. (eds.). Bilder. Bücher. Bytes. Zur Medialität des Alltags. 36. Kongress der Deutschen Gesellschaft für Volkskunde, Mainz, 23.-26. 09. 2007. Münster: Waxmann, 2009, pp. $60,67$.

94 VIEREGG, Hildegard Katharina.

Museumswissenschaften. Eine Einführung.

Paderborn: Fink, 2006, pp. 9, 63.

95 Ibidem, p. 153.
} 
"Museographie" vanished with the early 20th century. Till the 1990ies, the three other terms museology, "Museumskunde", and "Museumswissenschaft" were synonyms; contemporary trials to establish different German meanings have not (yet) reached common sense. Besides that, it is remarkable that none of these terms is mentioned in German dictionaries, from the oldest and still biggest Deutsches Wörterbuch (32 volumes, 1838-1961, founded by Jacob and Wilhelm Grimm), up to the last one, Deutsches Universalwörterbuch (2015).

\section{BIBLIOGRAPHY:}

AQUILINA, Janick Daniel. The Babelian tale of museology and museography: a history in words. Museology, International scientific electronic journal, 2011, Issue 6, pp. 1-20.

AUER, Hermann. Zur Einführung in den Begriff Museologie. In Museologie. Bericht über ein internationales Symposium, veranstaltet vom Deutschen Nationalkomitee des Internationalen Museumsrates (ICOM) in Zusammenarbeit mit der Deutschen UNESCO-Kommission, 1971 in München. Pullach: Verlag Dokumentation, 1973, pp. 10-12. ISBN 3-7940-5218-8.

AVE, Joachim. Museumspraxis und Museologie. Beiträge und Mitteilungen [Museum für Deutsche Geschichte Berlin], 1988, no. 14, pp. 39-42. ISSN 0232-623X.

BARING, Daniel Eberhard. Museographia Brunsvico Luneburgica. Oder Curiöse Nachricht Von denen Museis, Schatz-Kunst- und Raritäten-Cammern, so curiose Herren in den Braunschweig-Lüneburgischen Landen gesammlet und grösten Theils noch heutigen Tages in denselben aufbehalten werden. Lemgo: Meyer, 1744.

Beiträge zur sowjetischen Museologie. Berlin [East]: Institut für Museumswesen, 1978. BERGER, Siegfried. Vorwort. In Praktische Museumsarbeit. Hinweise für Leiter und Helfer von Heimatmuseen. Merseburg:
Museumsverband für die Provinz Sachsen und für Anhalt, 1939, pp. 5-7.

BERNHARDY, G. Grundlinien zur Encyklopädie der Philologie. Halle: Anton, 1832.

BÖTTIGER, Carl August. Andeutungen zu vier und zwanzig Vorträgen über die Archäologie im Winter 1806. Dresden: Arnold, 1806. Vol. 1.

BÖTTIGER, Carl August. Ueber Museen und Antikensammlungen. Eine archäologische Vorlesung, gehalten den 2. Januar 1807. Leipzig: Dyk, 1808.

BREUER, Werner. Die Entwicklung der Fachschule für Museologen 1954-1984. In Studien zur Geschichte des Museumswesens und der Museologie. Vol. 1. Berlin: Institut für Museumswesen, 1983, pp. 11-30.

FITTSCHEN, Klaus. Karl Otfried Müller und die Archäologie. In CALDER, William M. III and Renate SCHLESIER (eds.). Zwischen Rationalismus und Romantik. Karl Otfried Müller und die antike Kultur. Hildesheim: Weidemann, 1998, pp. 187216. ISBN 978-3-615-00198-3.

FLÜGEL, Katharina. Einführung in die Museologie. Darmstadt: Wissenschaftliche Buchgesellschaft, 2005. ISBN 3-534-09232-5.

FÜRBRINGER, M. [Review of] A. B. Meyer, Abbildungen von Vogel-Skeletten, Dresden 1879-1888. Journal für Ornithologie. Zeitschrift der Deutschen Ornithologen-Gesellschaft, 1891, vol. 39, pp. 86-92.

GRAESSE, Johann Georg Theodor. Die Museologie als Fachwissenschaft. Zeitschrift für Museologie und Antiquitätenkunde und verwandte Wissenschaften. 1883, no. 15, pp. 113115; no. 17, pp. 129-131.

GRAESSE, Johann Georg Theodor and T. Moritz HOFMANN. Was wir wollen. Zeitschrift für allgemeine Museologie und verwandte Wissenschaften, 1878, no. 1, pp. 1-2.

GRIBL, Albrecht A. Museologische Aus- und Fortbildung in Bayern und der BRD. Jahrbuch für Volkskunde und Museologie des Bezirksheimatmuseums Spittal/Drau, 1991, vol. 5, pp. 67-80.

GROTE, Andreas. Das Institut für Museumskunde bei den Staatlichen Museen Preußischer Kulturbesitz in Berlin. In VIEREGG, Hildegard et al. (eds.). Museumspädagogik in neuer Sicht. Erwachsenenbildung im Museum. Baltmannsweiler: Schneider, 1994, vol. 2, pp. 381-387. ISBN 3-87116-939-0.

HANSLOK, Andreas. Museologie und Archivwissenschaft in der DDR. Abgrenzung und Annäherung zweier Nachbarwissenschaften. Marburg: Tectum, 2008. ISBN 978-3-8288-9581-2.

HELD, Alexander. Demonstrative Naturgeschichte oder Erfahrungen und Belehrungen über das Sammeln, Präpariren, Klassificiren, Aufstellen, Verwahren und Demonstriren der Naturkörper aller drei Reiche. Stuttgart: Hallberg, 1845, pp. VIII-IX.

HERBST, Wolfgang and K. G. LEVYKIN (eds.). Museologie. Theoretische Grundlagen und Methodik der Arbeit in Geschichtsmuseen. Berlin [East]: Deutscher Verlag der Wissenschaften, 1988. ISBN 3-326-00229-7.

HOLTZHAUER, Helmut. Museumspädagogik und Museumswissenschaft. Neue Museumskunde, 1971, vol. 14, no. 2, pp. 86-89.

ISELT, Kathrin. „Sonderbeauftragter des Führers“. Der Kunsthistoriker und Museumsmann Hermann Voss (1884-1969). Köln: Böhlau, 2010. ISBN 978-3-412-20572-0.

JACOBI, Franz. Grundzüge einer Museographie der Stadt Rom zur Zeit des Kaisers Augustus. Part 1. Speyer: Gilardone, 1884.

JAHN, Ilse. Bemerkungen über museologische Forschung zu Problemen naturhistorischer Museen. Museologische Forschung. Beiträge und Informationen, 1982, vol. 3, pp. 3-6.

JAHN, Ilse. Der Freundschaftsvertrag zwischen dem Museum für Naturkunde Berlin und dem Naturhistorischen Museum Budapest und die Entwicklung einer naturhistorischen Museologie. Berichte zur Wissenschaftsgeschichte, 2001, vol. 24, pp. 155-162. ISSN 0170-6233.

JENCQUEL, Kaspar Friedrich. Museographia oder Anleitung zum rechten Begriff und nützlicher Anlegung der Museorum, oder Raritäten-Kammern [...]. Leipzig/Breslau: Hubert, 1727.

KLAUSEWITZ, Wolfgang. Kommentar der Redaktion. Museumskunde, 1992, vol. 57, no. 1, pp. 64-65. ISSN 0027-4178.

KOETSCHAU, Karl. Die Vorbildung der Museumsbeamten. Vortrag, gehalten 
auf der Würzburger Tagung 1918 [des Deutschen Museumsbundes]. Hamburg: Lütcke \& Wulff, 1918.

KORFF, Gottfried. Igel oder Kuscheltier? Anmerkungen zur Situation des Museums im Medienwandel der Informationsgesellschaft. In SIMON, Michael et al. (eds.). Bilder. Bücher. Bytes. Zur Medialität des Alltags. 36. Kongress der Deutschen Gesellschaft für Volkskunde, Mainz, 23.-26. 09. 2007. Münster: Waxmann, 2009, pp. 59-69. ISBN 978-3-8309-2179-0.

KUNTZ, Andreas. Technikgeschichte und Museologie. Beitrag zu einer Wissenschaftsgeschichte museumspädagogischer Probleme. Frankfurt am Main: Peter Lang, 1981. ISBN 3-8204-6857-9.

LADENDORF, Heinz. Museum und Universität. Museumskunde, 1960, vol. 29, pp. 73-87.

LAUFFER, Otto. Das historische Museum: Sein Wesen und Wirken und sein Unterschied von den Kunst- und Kunstgewerbe-Museen. Museumskunde, 1907, vol. 3, pp. 1-14, 78-99, 179-185, 222-245.

LEISCHING, Julius. Museumskurse. Museumskunde, 1905, vol. 1, pp. 91-96.

LIPP, Carola. Zum Verhältnis von Alltagsund Sachkulturforschung. Eine Antwort auf die kritischen Kommentare der Museologen Helmut Ottenjann und Uwe Meiners. Volkskunde in Niedersachsen, 1994, vol. 11, no. 2, pp. 85-93. ISSN 0176-1196.

MAIRESSE, François and André DESVALLÉES. Brève histoire de la muséologie, des Inscriptions au Musée vivant. In MARIAUX, Pierre Alain (ed.). L'objet de la muséologie. Neuchâtel: Institut d'Histoire de l'art et de Muséologie, 2005, pp. 1-50. ISBN 2-9700488-1-7.

MAIRESSE, François and André DESVALLÉES. Muséologie. Regard \& analyse. In DESVALLÉES, André and François MAIRESSE (eds.). Dictionnaire encyclopédique de muséologie. Paris: Armand Colin, 2011, pp. 345-383. ISBN 978-2-200-270037-7.

MAROEVIĆ, Ivo. Introduction to museology: the European approach. Munich: Müller-Straten, 1998, pp. 74-75. ISBN 3-932704-52-5.
MARTIN, Philipp Leopold. Die Praxis der Naturgeschichte. Ein vollständiges Lehrbuch über das Sammeln lebender und todter Naturkörper; deren Beobachtung, Erhaltung und Pflege im freien und gefangenen Zustand; Konservation, Präparation und Aufstellung der Sammlungen etc. Vol. 2. Dermoplastik und Museologie oder das Modelliren der Thiere und das Aufstellen und Erhalten von Naturaliensammlungen. 2nd, expanded and revised edition. Weimar: Voigt, 1880.

MENSCH, Peter van. Towards a methodology of museology. Zagreb: University of Zagreb, 1992, chapter 2 (no pagina). $\mathrm{PhD}$ thesis [accessed 2006-12-23; actually not available]. Has been available from www: <http://www. muuseum.ee/et/erialane_areng/ museologiaalane_ki/ingliskeelne kirjand/p_van_mensch_towar $>$.

MEYER, Andrea and Bénédicte SAVOY. Transnationale Museumswissenschaften. In KAMEL, Susan and Christine GERBICH (eds.). Experimentierfeld Museum. Internationale Perspektiven auf Museum, Islam und Inklusion. Bielefeld: Transcript, 2014, pp. 117-126. ISBN 978-3-8376-2380-2.

MONE, Franz Joseph. Die bildenden Künste im Großherzogthum Baden ehemals und jetzt. Topographie der Kunstwerke und Museographie in Baden mit Berücksichtigung der Militär-Architektur. Karlsruhe: self publishing of the author, 1889-1896.

MÖBIUS, Karl. Die Tiergebiete der Erde, ihre kartographische Abgrenzung und museologische Bezeichnung. Archiv für Naturgeschichte, 1891, vol. 57, no. 1, pp. 277-291.

MÜLLER, Karl Otfried. Handbuch der Archäologie der Kunst. Breslau: Max, 1830.

Museographia Oder Anleitung Zum rechten Begriff und nützlicher Anlegung der Museorum Oder Raritäten-Kammern... In Bayerische StaatsBibliothek digital [online]. [accessed 2018-11-22]. Available from www: <https://reader. digitale-sammlungen.de/de/fs1/object/ display/bsb10522844_00003.html>;

Museographia Oder Anleitung Zum rechten Begriff und nützlicher Anlegung der Mvseorvm, Oder Raritäten-Kammern...
In Digitale Sammlungen [online]. Universitäts- und Landesbibliothek Münster [accessed 2018-11-22]. Available from www: <https:// sammlungen.ulb.uni-muenster.de/urn/ urn:nbn:de:hbz:6:1-15073>.

NACHTIGALL, Horst. Politische Probleme der völkerkundlichen Museologie. Zeitschrift für Ethnologie, 1976, vol. 101, no. 2, pp. 298-303. ISSN 0044-2666.

PIPER, Ferdinand. Das christliche Museum der Universität zu Berlin 1849-1874. Gotha: Perthes, 1874.

RADEMACHER, Hellmut. Historische Bildkunde im Geschichtsmuseum. Beiträge und Mitteilungen [Museum für Deutsche Geschichte Berlin], 1988, no. 16, pp. 24-28. ISSN 0232-623X.

RADNÓTI-ALFÖLDI, Maria. Museologie. Ein mögliches Ergänzungsfach an der Universität. Bayerische Blätter für Volkskunde, 1982, vol. 9, no. 2, pp. 7494. ISSN 0720-8006.

RATHGEBER, Georg. Aufbau der niederländischen Kunstgeschichte und Museologie: Niederländische Münzen und Medaillen des Herzoglichen Museums zu Gotha. Weißensee: Grossmann, 1839. Vol. 1.

RAZGON, Avram M. Entwicklungen und Perspektiven der modernen Museologie. Beiträge und Mitteilungen [Museum für Deutsche Geschichte Berlin], 1988, no. 15, pp. 21-31. ISSN 0232-623X.

RITTERLING, E. (ed.). Museographie für die Jahre 1910-1912. Bericht der Römisch-Germanischen Kommission, 1912, vol. 7, pp. 26-252.

RÖSSLING, Udo. Museologie und die Zeitschrift „Neue Museumskunde“. Beiträge und Mitteilungen [Museum für Deutsche Geschichte Berlin], 1988, no. 15, pp. 78-80. ISSN 0232-623X.

SCHÄFER, Wilhelm. Naturwissenschaftliche Grafik - Museographik. In: Festschrift für Peter Wilhelm Meister zum 65. Geburtstag. Hamburg: Hauswedell, 1975, pp. 288296.

SCHEUNEMANN, Jan. „... dass für Dinge die einen so geringen gesellschaftspolitischen Nutzen haben so ein Aufwand gemacht wird." Fachschulausbildung von Museumsassistenten und Museologen in der DDR 1954-1964. In SCHIMPFF, Volker and Wieland FÜHR (eds.). Historia 
in museo. Festschrift für Frank-Dietrich Jacob zum 60. Geburtstag. Langenweißbach: Beier \& Beran, 2004, pp. 393-415. ISBN 3-930036-94-0.

SCHEUNEMANN, Jan.

„Gegenwartsbezogenheit und Parteinahme für den Sozialismus“. Geschichtspolitik und regionale Museumsarbeit in der SBZ/ DDR 1945-1971. Berlin: Metropol, 2009. ISBN 978-3-940938-35-0.

SCHMIDT, W. Museographie des Heimatmuseums der Gemeinde Schwanheim. Bericht der Freiwilligtätigen Arbeitsgemeinschaft zur Förderung der Heimatforschung [Frankfurt a. M.], 1926, no. 5, pp. 115-116.

SCHREINER, Klaus. Einführung in die Museologie - ein Beitrag zu den theoretischen Grundlagen der Museumsarbeit, Vol. 2. Neubrandenburg: private print, 1982.

SCHRÖDER, Hans. Lexikon der hamburgischen Schriftsteller bis zur Gegenwart. Vol. 3. Günther-Kleye. Hamburg: Perthes-Besser \& Mauke, 1857, pp. 488-489.

SCHWAHN, Britta-R. Koetschau. In Neue deutsche Biographie. Berlin: Duncker \& Humblot, 1980, vol. 12, pp. 410-411. ISBN 978-3-428-00181-1.

SEIZINGER, Johann Georg. Theorie und Praxis der Bibliothekswissenschaft. Grundlinien der Archivswissenschaft. Dresden: Ehlermann, 1863.

STECKNER, Cornelius. Das Museum Cimbricum von 1688 und die cartesianische „Perfection des Gemüthes". Zur Museumswissenschaft des Kieler Universitätsprofessors Johann Daniel Major (1634-1693). In GROTE, Andreas (ed.). Macrocosmos in microcosmo. Die Welt in der Stube. Zur Geschichte des Sammelns 1450 bis 1880. Opladen: Leske \& Budrich, 1994, pp. 603-628. ISBN 3-8100-1048-0.
STEGMANN, Hans. Zur Geschichte der Herstellung und Verzierung der geschlagenen Messingbecken. Mitteilungen aus dem germanischen Nationalmuseum. 1899, no. 3, p. 19.

STRÁNSKÝ, Zbyněk. Die theoretischen Grundlagen der Museologie als Wissenschaft. In AUER, Hermann (ed.). Museologie. Neue Wege - neue Ziele. Bericht über ein internationales Symposium, veranstaltet von den ICOM Nationalkomitees der Bundesrepublik Deutschland, Österreichs und der Schweiz, 1988 am Bodensee. München: Saur, 1989, pp. 38-47. ISBN 3-598-10809-9.

VIEREGG, Hildegard Katharina.

Museumswissenschaften. Eine Einführung. Paderborn: Fink, 2006. ISBN 978-3-8252-2823-1.

VOSSEN, Rüdiger et al. Bilanz und Zukunft der Völkerkunde-Museen. Zeitschrift für Ethnologie, 1976, vol. 101, no. 2, pp. 198-205. ISSN 0044-2666.

WAIDACHER, Friedrich. Grundgedanken zu einer museologieorientierten Praxis. Museologie online [online] 2001, vol. 3, pp. 84-100 [accessed 2018-08-30]. Available from www: <http://www. historisches-centrum.de/m-online/>.

WAIDACHER, Friedrich. Handbuch der Allgemeinen Museologie. 2nd edition. Wien: Böhlau, 1996, pp. 125-134. ISBN 3-205-98445-5.

WEISS, Richard. Volkskunde der Schweiz. Grundriss. Erlenbach-Zürich: Rentsch, 1946, p. IX.

WIESE, Erich. Museumskunde als Lehrfach. Museumskunde, 1960, vol. 29, pp. 93-95.

WULFF, Oskar. August Schmarsow zum 80. Geburtstag. Zeitschrift für Kunstgeschichte, 1933, vol. 2, no. 3, pp. 207-209.

\section{MARKUS WALZ}

Hochschule für Technik,

Wirtschaft und Kultur Leipzig,

Fakultät Medien.

Leipzig, Bundesrepublik Deutschland

markus.walz@htwk-leipzig.de

Markus Walz is Professor of

Theoretical and Historical

museology at Leipzig University

of Applied Sciences. He studied

European ethnology and doctoral

studies in History. He did research

traineeship at the Landesmuseum

Koblenz, worked as Museum

consultant for Eastern Westphalia

and Lippe in the Westphalian

Museum Office in Münster.

Since 2001 he works at Leipzig

University of Applied Sciences.

Markus Walz je profesorem teoretické a historické muzeologie na Vysoké škole pro techniku, hospodářství a kulturu v Lipsku (HTWK). Vystudoval evropskou etnologii a získal doktorát v oboru historie. Odbornou vědeckou praxi absolvoval v Zemském muzeu v Koblenz, pracoval jako muzejní poradce pro Východní Vestfálsko a Lippe ve Vestfálském úřadu pro muzea v Münsteru. 